\title{
Copyright Infringement in the Ether: RAM Buffering and the Copyright Act's Duration Requirement ${ }^{*}$
}

\section{INTRODUCTION}

Home television watchers have long enjoyed the right to "timeshift," or record a program for later viewing. ${ }^{1}$ In the 1980s, time-shifting was accomplished using a videocassette recorder (VCR) and a blank tape. $^{2}$ This technology was eventually replaced with digital video recorders (DVRs), devices that write television content onto a hard drive. The right of television watchers to time-shift was held to be fair use of copyrighted content by the Supreme Court in the landmark case Sony Corp. of America v. Universal City Studios, Inc. ${ }^{3}$ Time-shifting was recently put under renewed scrutiny regarding a novel digital video recording technology developed by Cablevision, a cable television provider. ${ }^{4}$ The Remote Storage Digital Video Recorder (RS-DVR) is a service that allows cable subscribers to record and play back video content in the absence of a set-top DVR. ${ }^{5}$ Instead, time-shifted programs are copied onto remote servers controlled and maintained at Cablevision's head-end, ${ }^{6}$ a central facility that houses the hardware on which the content is copied and stored. ${ }^{7}$

\footnotetext{
Daniel J. Buller. J.D. candidate 2011, University of Kansas School of Law; B.A. 2007, Wichita State University. I would like to thank the Kansas Law Review staff and board for their hard work during the editing process. I would also like to send a special thanks to Professor Mike Kautsch for his invaluable guidance throughout the writing of this Note. Finally, and most importantly, I would like to thank my wife, Natasha. Without her patience and support, it would be more than just embodiments of data in RAM that failed to last for more than a transitory duration.

1. See Sony Corp. of Am. v. Universal City Studios, Inc., 464 U.S. 417, 454-55 (1984) (stating that "home time-shifting is fair use").

2. See id. at 420 (stating that "[s]ome members of the general public use video tape recorders sold by petitioners to record . . . broadcasts").

3. Id. at $454-55$.

4. Cartoon Network LP v. CSC Holdings, Inc. (Cablevision II), 536 F.3d 121, 124 (2d Cir. 2008).

5. Id. at $123-24$.

6. Twentieth Century Fox Film Corp. v. Cablevision Sys. Corp. (Cablevision I), 478 F. Supp. 2d 607, 611 (S.D.N.Y. 2007), rev'd in part, vacated in part, Cablevision II, 536 F.3d 121.

7. Cablevision II, 536 F.3d at 124.
} 
Section 106 of the Copyright Act prohibits the copying of copyrighted material by anyone other than the owner of the copyright. ${ }^{8}$ The Copyright Act defines "copies" as "material objects ... in which a work is fixed by any method ... and from which the work can be... reproduced." The Act further defines a copy as "fixed" when "its embodiment in a copy ... is sufficiently permanent or stable to permit it to be perceived, reproduced, or otherwise communicated for a period of more than a transitory duration." ${ }^{10}$

The exact nature of this "duration" requirement is unclear because of a case brought by Cartoon Network and other content providers against Cablevision. ${ }^{11}$ The content providers alleged that by buffering copyrighted content in RAM, the RS-DVR infringed upon their exclusive reproduction rights. ${ }^{12}$ Cablevision denied that the buffered data were sufficiently fixed to constitute copies as defined by the Copyright Act. ${ }^{13}$ Whether the buffered data met the duration requirement of section 101 of the Copyright Act was central to the suit. ${ }^{14}$ Holding in favor of Cablevision, the Second Circuit restricted its analysis of the duration requirement to a timeline. ${ }^{15}$ The court held that because the RS-DVR buffers data for no more than 1.2 seconds, the duration requirement was not met and the copyrighted works were thus not fixed in the buffer. ${ }^{16}$

The timeline analysis employed by the Second Circuit in Cablevision II leaves in disarray copyright jurisprudence regarding data fixed in RAM. Data fixed in RAM are typically created as part of an automated process that is entirely transparent to the user. ${ }^{17}$ The time that data are

8. 17 U.S.C. § 106 (2006) (stating that "the owner of [the] copyright ... has the exclusive right[] . . . to reproduce the copyrighted work in copies”).

9. Id. $\S 101$.

10. Id.

11. Cablevision II, 536 F.3d 121.

12. Id. at 123. The plaintiffs in Cablevision II actually alleged three different copyright infringements by Cablevision. First, by "briefly storing data [in RAM], Cablevision would make copies of protected works and thereby directly infringe plaintiffs' exclusive right of reproduction.” Id. at 125. Second, "by copying programs onto [hard disks owned and maintained by Cablevision], Cablevision would again directly infringe the reproduction right." Id. Third, "by transmitting the data from [Cablevision's hard disks] to its RS-DVR customers in response to a 'playback' request, Cablevision would directly infringe plaintiffs' exclusive right of public performance.” Id. This Note will focus on the first allegation only.

13. Id.

14. Id.

15. Id. at 130 .

16. Id.

17. U.S. COPYRIGHT OFFICE, DMCA SECTION 104 REPORT 107 (2001), available at http://www.copyright.gov/reports/studies/dmca/sec-104-report-vol-1.pdf [hereinafter DMCA REPORT]. 
embodied in RAM can vary greatly because of the underlying hardware and software that controls the embodiment. In light of modern computer technology, measuring the permanence of data fixed in RAM strictly on a timeline produces arbitrary results. For example, the lawfulness of competing RS-DVRs may hinge on a length of time too small to be humanly perceived because one service uses more advanced hardware or more efficient software than the other. The RS-DVR that is able to buffer RAM for a shorter length of time will be lawful, whereas one that buffers data for a greater length will be unlawful. This confounding result is true even though the overall functions of the systems are identical. In contrast, if the duration requirement were understood in terms of the purpose underlying the embodiment of data in RAM, the issue of duration would be rationally and fairly resolved.

Part II of this Note describes in detail the duration requirement of the Copyright Act. It also provides additional background information on the lawfulness of home time-shifting, beginning with the recording of television programs onto Betamax videocassettes in the early 1980s. Part II will also discuss the Cablevision cases as they relate to the duration requirement and data embodied in RAM. Part III discusses how the Cablevision II court's timeline analysis neither rationally resolves the issue of whether Cablevision's RS-DVR meets the duration requirement nor provides an adequate test for future courts. In addition, Part III introduces and discusses the purpose-based analysis of the duration requirement, an alternative to the timeline analysis that avoids the pitfalls inherent in the timeline analysis.

\section{BACKGROUND}

\section{A. Copyright Infringement}

"To establish infringement, two elements must be proven: (1) ownership of a valid copyright, and (2) copying of constituent elements of the work that are original." 18 A copyright infringer is "anyone who trespasses into [the copyright holder's] exclusive domain by using or authorizing the use of the copyrighted work" in a way prohibited by the Copyright Act. ${ }^{19}$ The owner of a copyright has the exclusive right to "reproduce the copyrighted work in copies." 20 This is the copyright

\footnotetext{
18. Feist Publ’ns, Inc. v. Rural Tel. Serv. Co., 499 U.S. 340, 361 (1991).

19. Sony Corp. of Am. v. Universal City Studios, Inc., 464 U.S. 417, 433 (1984).

20. 17 U.S.C. $\S 106$ (2006).
} 
holder's "reproduction right" 21 and anyone who violates it "is an infringer of the copyright.",22

Conversely, a copyright holder's reproduction right is not infringed when the reproduction is a "fair use" of the copyrighted work. ${ }^{23}$ "The fair use doctrine ... 'permits . . c courts to avoid rigid application of the copyright statute when ... it would stifle the very creativity which that law is designed to foster." 24 "The ultimate test of fair use . . . is whether the copyright law's goal of 'promot[ing] the Progress of Science and useful Arts", 25 "would be better served by allowing the use than preventing it." 26

\section{B. The Copyright Act's Duration Requirement}

Consider a novel-reproduced by someone who later destroys the reproduction. For how long must the novel be embodied in the reproduction before it is a copy? In the early twentieth century, a copy could only be infringing if "perceptible to the naked eye." 27 The current Copyright Act, in contrast, provides a more nuanced duration requirement. Section 101 of the Act provides that a work is fixed when it is "sufficiently permanent or stable to permit it to be perceived, reproduced, or otherwise communicated for a period of more than transitory duration." 28 The Copyright Act does not define transitory duration.

The legislative history of the Copyright Act is informative on fixation and the duration requirement. For example, the House Report provided that, "[i]f the program content is transmitted live to the public while being recorded at the same time" the content is fixed. ${ }^{29}$ "On the other hand, the definition of 'fixation' would exclude from the concept purely evanescent or transient reproductions such as those projected

\footnotetext{
21. Cablevision II, 536 F.3d at 127.

22. 17 U.S.C. $\S 501$.

23. Id. § 107.

24. Campbell v. Acuff-Rose Music, Inc., 510 U.S. 569, 577 (1994) (quoting Stewart v. Abend, 495 U.S. 207, 236 (1990)).

25. Castle Rock Entm't, Inc. v. Carol Publ'g Group, Inc., 150 F.3d 132, 141 (2d Cir. 1998) (quoting U.S. CONST. art. I, § 8, cl. 8).

26. Id. (quoting Arica Inst., Inc. v. Palmer, 970 F.2d 1067, 1077 (2d Cir. 1992)).

27. 2 Melville B. NimMER \& DAVID NimMER, NimMER ON COPYRight § 8.08[A][1] (2008); see also White-Smith Music Publ'g Co. v. Apollo Co., 209 U.S. 1, 17 (1908) (stating that "[i]t is not susceptible of being copied until it has been put in a form which others can see”).

28. 17 U.S.C. § 101.

29. H.R. REP. No. 94-1476, at 52 (1976), reprinted in 1976 U.S.C.C.A.N. 5659, 5665.
} 
briefly on a screen ... or captured momentarily in the 'memory' of a computer." 30 This language seems to exclude data embodied in RAM from the definition of fixed. However,

on investigation, that claim does not hold up. The ... House Report was formulated in an era of batch processing rather than personal computers-the same page of that report refers to "computer punch cards." In an age of punch cards, fixation in memory was indeed momentary. By contrast, RAM copies in today's environment often last far longer than momentarily-even for days or months. Accordingly, that language formulated in 1976 cannot be deemed to control those copies that remain in RAM for extended periods. ${ }^{31}$

Congress was apparently aware that data embodied by automated computer systems might change the landscape of copyright law. As stated in the House Report, "it has become increasingly apparent that in one major area the problems are not sufficiently developed for a definitive legislative solution. This is the area of computer uses of copyrighted works: the use of a work 'in conjunction with automatic systems capable of storing, processing, retrieving, or transferring information." 32 In this comment, the House Report explicitly acknowledged the issue of whether data are fixed within RAM embodiments by computer systems and reserved the issue for resolution until the Commission on New Technological Uses (CONTU), which was at the time conducting a "thorough study of the emerging patterns in this field," 33 made a definite recommendation "to deal with the situation."34 Congress later accepted CONTU's recommendation that "the loading of software into a computer implicates the copyright owner's rights, but is exempt from liability under specified circumstances." 35

\footnotetext{
30. Id. at 53 .

31. 2 NimMER \& NiMMER, supra note 27, § 8.08[A][2].

32. H.R. REP. NO. 94-1476, at 116.

33. Id.

34. Id.

35. 2 NIMMER \& NimMER, supra note 27, § 8.08[A][4]. While applicable to fixation and the duration requirement, CONTU's recommendation was directed explicitly at 17 U.S.C. § 117, and the specified circumstances exempt from liability are included therein. See NAT'L COMM'N ON NEW TECHNOLOGICAL USES OF COPYRIGHTED WORKS, FINAL REPORT OF THE NATIONAL COMMISSION ON NEW TECHNOLOGICAL USES OF COPYRIGHTED WORKS 12-13 (1978). CONTU's report refers to the Copyright Act's definition of "copy" applying to machine-readable versions of works within the computer context. Id.
} 


\section{Time-Shifting: A Trip Back to the '80s with a Betamax Machine}

The 1980s were a great time for television watchers. The '80s gave us such veritable television classics as Miami Vice, Magnum, P.I., Cheers, and L.A. Law, as well as movies such as Fast Times at Ridgemont High, The Empire Strikes Back, and, of course, This is Spinal Tap. In addition to an embarrassment of television riches, consumers of such fare had more choices than ever on how and when they watched television. With the advent of VCRs, consumers had the option of "recording a program to view it once at a later time." 36 Sony advertised its version of the VCR, ${ }^{37}$ called Betamax, as a device that would provide home television watchers the ability to copy television programs for later viewing. ${ }^{38}$ The United States Supreme Court defined the practice as time-shifting in the landmark decision of Sony Corp. of America v. Universal City Studios, Inc. ${ }^{39}$ The Court described it as enabling "viewers to see programs they otherwise would miss because they are not at home, are occupied with other tasks, or are viewing a program on another station at the time of a broadcast that they desire to watch." 40 Time-shifting allowed people to watch any show whenever and as often as they liked, so long as they had a VCR and a tape on which to record the program. ${ }^{41}$

At the time of the Sony case, members of the film and television industries responded negatively to the ability and right of consumers to copy television shows and movies at will. ${ }^{42}$ Just before the Sony case was decided, Jack Valenti, then-president of the Motion Picture Association of America, boldly declared that the film industry's "total future depends on its protection from the savagery and the ravages of this

36. Sony Corp. of Am. v. Universal City Studios, Inc., 464 U.S. 417, 423 (1984).

37. Technically, Sony's device was a videotape recorder, or VTR. See id. at 420. For purposes of this Note, there is no difference between a VCR and a VTR, and the recording devices at issue in the Sony case will be referred to as VCRs.

38. See Home Recording of Copyrighted Works: Hearings Before the Subcomm. on Courts, Civil Liberties, and the Admin. of Justice of the H. Comm. on the Judiciary, 97th Cong. 5 (1982) [hereinafter Home Recording of Copyrighted Works] (statement of Jack Valenti, President, Motion Picture Ass'n of Am., Inc.) (“[T]hese machines [VCRs] are advertised for one purpose in life. ... [T] heir only single mission . . to copy copyrighted material that belongs to other people.”).

39. Sony, 464 U.S. at 423.

40. Id.

41. Id. at 422-23.

42. See Home Recording of Copyrighted Works, supra note 38, at 4 (statement of Jack Valenti, President, Motion Picture Ass'n of Am., Inc.) (stating that the "video cassette recorder and the blank tape threaten profoundly the life-sustaining protection ... on which copyright owners depend, on which film people depend, on which television people depend and it is called copyright”). 
machine.... [T] Boston strangler is to the woman home alone." 43 In one respect, the overwhelmingly negative response by content providers was unsurprising. The Sony case was considered

unprecedented in the history of copyright litigation.

Perhaps one reason ... lies in the fact that video cassette recorders constitute the most significant new development in the entertainment industry ... since the introduction of television itself, with [millions of machines sold] .... And the [Court's] decision has raised the spectre of making each and every use of these machines to date a copyright infringement.

Theoretically... [the Court's decision] could subject millions of private citizens to damages for copyright infringement and subject the manufacturers and retailers of the recorders to a financial liability, perhaps, even exceeding their entire net worth .... 44

Despite the entreaties of the film industry, the Supreme Court in Sony held that home time-shifting was lawful. ${ }^{45}$ Two aspects of the Sony Court's opinion are relevant to this Note. First, because the content providers were unable to demonstrate that some likelihood of harm would result, the Court held home time-shifting to be fair use. ${ }^{46}$ Therefore, individuals who choose to copy television programs using a VCR are not liable for copyright infringement. ${ }^{47}$ Second, Sony had

demonstrated a significant likelihood that substantial numbers of copyright holders who license their works for broadcast on free television would not object to having their broadcasts time-shifted by private viewers. And [plaintiffs] failed to demonstrate that timeshifting would cause any likelihood of nonminimal harm to the potential market for, or the value of, their copyrighted works.... The Betamax is, therefore, capable of substantial noninfringing uses. Sony's sale of such equipment to the general public does not [therefore] constitute contributory infringement of [plaintiffs'] copyrights. ${ }^{48}$

\section{Id. at 8.}

44. Id. at 1-2 (statement of Hon. Robert W. Kastenmeier, Chairman, Subcomm. on Courts, Civil Liberties and the Admin. of Justice of the H. Comm. on the Judiciary).

45. Sony, 464 U.S. at 456.

46. Id. at 454-55. Fair use is defined as "[a] reasonable and limited use of copyrighted work without the author's permission.” BLACK’s LAW DICTIONARY 676 (9th ed. 2009).

47. Sony, 464 U.S. at $454-55$.

48. Id. at 456 . 


\section{Cartoon Network Gets Animated About Cablevision's New RS-DVR}

\section{The Evolution of Time-Shifting}

As the '80s waned, television watchers graduated from VCRs to DVRs. As opposed to the tape-based technology of VCRs, DVRs stored video content on a hard drive within the device. ${ }^{49}$ Although the DVR substantially improved upon the convenience and functionality offered by its predecessors, the basic time-shifting purpose at its core remained the same. Like VCRs, these devices allow home television watchers to record a program for later viewing. ${ }^{50}$ Furthermore, like VCRs, DVRs only record content when the user directs it to do so, typically by using a remote control. ${ }^{51}$ For example, if the DVR owner chooses not to record this week's episode of The Simpsons, the device takes no action whatsoever in relation to that program.

In March 2006, Cablevision announced plans to introduce the RSDVR. $^{52}$ The RS-DVR, from the perspective of the time-shifting consumer, functioned identically to the set-top DVRs that Cablevision had been providing to its customers, for a fee, since $2004 .^{53}$ While Cablevision ultimately controls which channels are available for timeshifting by the RS-DVR system, ${ }^{54}$ the subscriber must choose to press the record button on the remote control if they want to time-shift any program. $^{55}$ The on-screen menus, remote control, and recording and playback functionality all look identical on Cablevision's RS-DVR compared to its set-top DVRs. ${ }^{56}$ From the customer's perspective,

the processes of recording and playback on the RS-DVR are similar to that of a standard set-top DVR. Using a remote control, the customer can record programming by selecting a program in advance from an onscreen guide, or by pressing the record button while viewing a given

49. Twentieth Century Fox Film Corp. v. Cablevision Sys. Corp. (Cablevision I), 478 F. Supp. 2d 607, 611 (S.D.N.Y. 2007), rev'd in part, vacated in part, Cartoon Network LP v. CSC Holdings, Inc. (Cablevision II), 536 F.3d 121 (2d Cir. 2008).

50. Id.

51. Id. at 614 .

52. Id. at 609.

53. Id. at 612 .

54. Cablevision II, 536 F.3d at 125.

55. Id.

56. Cablevision I, 478 F. Supp. 2d at 612. 
program. A customer cannot, however, record the earlier portion of a program once it has begun.

The primary function of Cablevision's RS-DVR, as with its set-top DVR, is to give cable subscribers the ability to time-shift television content. $^{58}$ The only difference, from the subscriber's perspective, is that no hardware is physically present in the home; rather, the recording and storing of the content are all performed at Cablevision's head-end. ${ }^{59}$ Before rolling out the RS-DVR, Cablevision notified content providers of its intention to offer the product to subscribers. ${ }^{60}$ Cablevision sought no additional licenses from the content providers. ${ }^{61}$

\section{RS-DVR RAM Buffering}

For television watchers to remotely time-shift a program using the RS-DVR, Cablevision must manipulate the content as the programs are broadcast. Ordinarily, Cablevision gathers the streams of program data from the various content providers, aggregates them into a single broadcast stream, "and transmit[s] those programs [in real time] into the homes of their subscribers via coaxial cable."62 Under the RS-DVR system, however, this single stream of data is split into two separate streams - one stream is broadcast to the subscribers' television sets, and the other continues through the RS-DVR for copying and rebroadcast purposes. $^{63}$

Before determining whether any customer record request exists for a program, the RS-DVR stores the data in several areas of RAM. This action is taken solely by Cablevision before the RS-DVR receives any customer request. ${ }^{64}$

It is undisputed that Cablevision, not any customer or other entity, takes the content from one stream of programming, after the split [of the broadcast stream], and stores it, one small piece at a time, in

$[R A M] \ldots$. As a result, the information is buffered before any

57. Cablevision II, 536 F.3d at 125.

58. See id. at 124 ("[T] alone DVR to record cable programming.... [C]ustomers may then receive playback of those programs through their home television sets.”).

59. Id. at $124-25$.

60. Id. at 124.

61. Id.

62. Id.

63. Id.

64. Id. 
customer requests a recording, and would be buffered even if no such request were made. The question is whether, by buffering the data that make up a given work, Cablevision "reproduce[s]" that work "in copies," and thereby infringes the copyright holder's reproduction right.

A brief overview of how data are stored in RAM will be helpful to understand the operation of Cablevision's RS-DVR. Data are stored in RAM differently than, for example, on a hard drive. RAM-stored data only remain until either the power to the system is turned off or the data are overwritten. ${ }^{66}$ Furthermore, "[a]ll of the familiar activities that one performs on a computer... necessarily entail making reproductions in RAM. These reproductions generally are made automatically, and transparently to the user-i.e., without the user being aware that copies are being made." ${ }^{\circ}$

In Cablevision's RS-DVR system, the court looked at two areas of RAM when determining whether copyright infringement occurred. ${ }^{68}$ The first was the primary ingest buffer, which was the area of RAM in which the system queried all customer record requests to determine whether the data should ultimately be copied to the RS-DVR's hard disks. ${ }^{69}$ The second area of RAM was the Broadband Media Router (BMR). ${ }^{70}$ The BMR "buffers the data stream, reformats it, and sends it to [Cablevision's servers]." ${ }^{71}$ Specifically, the BMR "converts the bitrate of the stream" so that it is more efficient. ${ }^{72}$ The BMR also splits and reformats the stream so that it can be routed and stored on Cablevision's hard disks. ${ }^{73}$ The RAM data at issue on the RD-DVR were never stored for more than one tenth of a second before being overwritten by new data. ${ }^{74}$ These data comprised at most 1.2 seconds of programming. ${ }^{75}$

65. Id. at 127 (internal citation omitted).

66. DMCA REPORT, supra note 17 , at 107.

67. Id.

68. Cablevision II, 536 F.3d at 124.

69. Id.

70. Id.

71. Id.

72. Twentieth Century Fox Film Corp. v. Cablevision Sys. Corp. (Cablevision I), 478 F. Supp. 2d 607, 613 (S.D.N.Y. 2007), rev'd in part, vacated in part, Cablevision II, 536 F.3d 121.

73. Id.

74. Cablevision II, 536 F.3d at 124.

75. Id. at $124-25$. 


\section{Cablevision I}

Copyright holders of television content responded negatively to Cablevision's new product ${ }^{76}$ and sued Cablevision for declaratory and injunctive relief, alleging that operation of the RS-DVR would "infringe their exclusive rights to both reproduce and publicly perform their copyrighted works." ${ }^{\text {,7 }}$ The district court granted summary judgment in favor of the content providers and "enjoined Cablevision from operating the RS-DVR system without licenses."

Cablevision's RS-DVR system stores data in RAM to allow the system to reformat the data stream and "automatically inquire[] as to whether any customers want to record any ... programming.,79 Cartoon Network claimed that Cablevision's storing of data in RAM meant that its RS-DVR system unlawfully copied content as it was buffered. ${ }^{80}$ Cablevision argued that the data buffered in RAM "were not 'fixed' and therefore were not 'copies' as defined by the Copyright Act." 81

The district court concluded that the data buffered in RAM were sufficiently fixed. $^{82}$ Because of the data embodied in RAM, entire programs were being reproduced. Therefore, "[c]learly, the buffer copies are capable of being reproduced." 83 In addition, the district court found it significant that, when taken as a whole, the data embodied in RAM consisted of entire programs being buffered, albeit one small piece at a time. $^{84}$

76. See, e.g., Stephanie Clifford, Supreme Court Allows Wider DVR Use, N.Y. TIMES, June 30, 2009, at B6 (stating that "[b]esides the licensing issue, programmers are generally opposed to anything that makes DVRs more pervasive, because consumers using DVRs tend to skip advertisements"); John Eggerton, Outside the Box, DAILY VARIETY, June 30, 2009, at 1 (stating that "DVR's ad-skipping function takes aim at the primary revenue source for the broadcast nets ... to draw the mass audiences that command the biggest bucks from advertisers and use established shows as a springboard for launching others”); David G. Savage, Video On Demand Goes to Court: TV Networks \& Film Studios Are Hoping that Justices Will Block a Cable Service They Say Violates Their Rights, L.A. TimES, Jan. 9, 2009, at C3 ("TV networks and film studios said the appeals ruling was wrong as matter of law. Unless it is reversed... it will have 'sweeping implications in the digital age.”').

77. Cablevision II, 536 F.3d at 124.

78. Id.

79. Id.

80. Id. at 125 .

81. Id.

82. Twentieth Century Fox Film Corp. v. Cablevision Sys. Corp. (Cablevision I), 478 F. Supp. 2d 607, 621-22 (S.D.N.Y. 2007), rev'd in part, vacated in part, Cablevision II, 536 F.3d 121.

83. Id. at 621 .

84. Id. 


\section{Cablevision II}

The Second Circuit reversed the district court's decision and vacated the injunction against Cablevision. ${ }^{85}$ The circuit court held that operation of Cablevision's RS-DVR "would not directly infringe plaintiffs' exclusive rights to reproduce and publicly perform their copyrighted works." ${ }^{\prime 6}$ While the Second Circuit's rationale included a discussion about the technical inner-workings of the RS-DVR system, ultimately it did not "believe that [the] RS-DVR customer is sufficiently distinguishable from a VCR user to impose liability" ${ }^{\text { } 7}$ and followed the reasoning of Sony. The court concluded that the language of the Copyright Act

imposes two distinct but related requirements: the work must be embodied in a medium, i.e., placed in a medium such that it can be perceived, reproduced, etc., from that medium (the "embodiment requirement"), and it must remain thus embodied "for a period of more than transitory duration" (the "duration requirement”). Unless both requirements are met, the work is not "fixed" in the buffer, and, as a result, the buffer data is not a "copy" of the original work whose data is buffered. $^{88}$

The Second Circuit further concluded that the

district court mistakenly limited its analysis primarily to the embodiment requirement. As a result of this error, once it determined that the buffer data was "[c]learly ... capable of being reproduced," i.e., that the work was embodied in the buffer, the district court concluded that the work was therefore "fixed" in the buffer, and that a copy had thus been made. ${ }^{89}$

Regarding the embodiment requirement, it was not seriously disputed by the parties that the plaintiffs' works were

"embodied" in the buffer. ... Data in the ... buffer can be copied onto the ... hard disks [of the RS-DVR system] if a user has requested a recording of that data. Thus, a work's "embodiment" in [the] buffer "is

\footnotetext{
85. Cablevision II, 536 F.3d at 140.

86. Id.

87. Id. at 131 .

88. Id. at 127 (internal citation omitted).

89. Id.
} 
sufficiently permanent or stable to permit it to be perceived, [or] reproduced ....,90

This was especially true in light of the fact that, in the aggregate, "every second of an entire work is placed, one second at a time, in the buffer." The critical question for the court, therefore, was whether the embodiment met the duration requirement. ${ }^{92}$

The Cablevision II court concluded that the data buffered in RAM by the RS-DVR failed the duration requirement, and therefore no copies, as defined by the Copyright Act, existed. ${ }^{93}$ In making its decision, the court noted that the data buffered by the RS-DVR are "rapidly and automatically overwritten" as soon as they are processed, and data never reside in the buffer for more than 1.2 seconds before being overwritten. ${ }^{94}$

\section{ANALYSIS}

\section{A. Measuring the Immeasurable: How Long Is Transitory, Anyway?}

Transitory is an adjective, defined by Black's Law Dictionary as "[t]hat passing from place to place; capable of passing or being changed from one place to another." ${ }^{95}$ Using this definition, a facial reading of the Copyright Act provides that a work is fixed when its "embodiment in a copy ... is sufficiently permanent or stable to permit it to be perceived, [or] reproduced" 96 for a period or use greater than merely passing from place to place. Other dictionaries define transitory more strictly as a word measuring duration on a timeline. For example, Merriam Webster's Collegiate Dictionary defines transitory as "tending to pass away: not persistent," or "of brief duration." 97 According to these sources, the Act would more appropriately be construed as meaning that a work is fixed when its "embodiment in a copy ... is sufficiently permanent or stable to permit it to be perceived, [or] reproduced"98 for

90. Id. at 129 .

91. Id.

92. Id.

93. Id. at 130.

94. Id.

95. BLACK'S LAW DiCTIONARY 1637 (9th ed. 2009).

96. 17 U.S.C. $\S 101$ (2006).

97. MERRIAM WebSTER's COlLEgIATE DictionaRy 1254 (10th ed. 1995); see also RANDOM HOUSE WEBSTER's COLLEGE DiCTIONARY 1417 (1991) (defining transitory as "not lasting, enduring, permanent, or eternal" or "lasting only a short time; brief; short-lived; temporary").

98. 17 U.S.C. § 101. 
greater than a brief duration of time. According to a 2001 report by the U.S. Copyright Office on the Digital Millennium Copyright Act (DMCA), which was designed to "bring[] U.S. copyright law squarely into the digital age," ${ }^{99}$ the Copyright Act

\begin{abstract}
does not define "transitory duration" directly. Since permanence is not required for fixation, "transitory" must denote something shorter than "temporary." "Transitory" must also denote something less than "ephemeral," as that term is used in the Copyright Act, since the Act confirms that "ephemeral recordings" are fixed by providing a specific exemption for "ephemeral recordings" lasting up to six months. Courts have not attempted to formulate a general rule defining how long a reproduction must endure to be "fixed," deciding instead on a case-bycase basis whether the particular reproduction at issue sufficed. ${ }^{100}$
\end{abstract}

The Second Circuit, in Cablevision II, construed transitory strictly on a timeline, stating that "[n]o bit of data remains in any buffer for more than a fleeting 1.2 seconds ... [and] each bit of data... is rapidly and automatically overwritten as soon as it is processed."101 While noting that the duration requirement was "necessarily fact-specific, and other factors not present here may alter the duration analysis significantly,"102 in the present case, the facts "strongly suggest that the works ... are embodied in the buffer for only a 'transitory' period, thus failing the duration requirement." ${ }^{\prime 03}$ The court declined to give any examples of the absent factors that could significantly alter the duration requirement analysis.

Rather than construing transitory duration strictly on a timeline, the Copyright Office construed Congress's intent as restricting reproductions "from which economic value can be derived."104 Further,

[t]he economic value derived from a reproduction lies in the ability to copy, perceive or communicate it. [Thus] [u]nless a reproduction manifests itself so fleetingly that it cannot be copied, perceived or communicated, the making of that copy should fall within the scope of the copyright owner's exclusive rights. The dividing line, then, can be drawn between reproductions that exist for a sufficient period of time to be capable of being 'perceived, reproduced, or otherwise

\footnotetext{
99. S. REP. NO. 105-190, at 2 (1998).

100. DMCA REPORT, supra note 17 , at 110-11.

101. Cartoon Network LP v. CSC Holdings, Inc. (Cablevision II), 536 F.3d 121, 129-30 (2d Cir.

102. Id. at 130 .

103. Id.

104. DMCA REPORT, supra note 17 , at 111.
} 2008). 
communicated' and those that do not. As a practical matter ... this would cover the temporary copies that are made in RAM in the course of using works on computers and computer networks. ${ }^{105}$

The Copyright Office came to this conclusion because

attempting to draw a line based on duration may be impossible.... Even if this distinction were possible under the statute, the concept of permanence is not helpful in this context. Magnetic disks and tapes can be erased; printed works decompose over time, or can be destroyed deliberately or accidentally. Separating some temporary copies from others based on their duration poses similar difficulties. How temporary is temporary? Hours? Minutes? Seconds? Nanoseconds? The line would be difficult to draw, both in theory and as a matter of proof in litigation. ${ }^{106}$

The DMCA Report buttressed its conclusion that RAM copies typically meet the duration requirement by noting that section 117 of the Copyright Act provides that "it is not an infringement for the owner of a copy of a computer program to make or authorize the making of another copy ... of that ... program” so long as the created copy is "an essential step in the utilization of the computer program [solely] in conjunction with a machine" or that the copy is solely for "archival purposes."107 The "new copy" referenced in section 117 "is the copy made in RAM when the program is executed." 108 The DMCA Report concluded that section 117 would not have been necessary "if reproductions in RAM could not be copies. It would be unreasonable to interpret the definitions in section 101 in such a way that it would render section 117 superfluous." 109 In the end, the DMCA Report concluded that a copy is within the copyright owner's exclusive rights unless it "manifests itself so fleetingly that it cannot be copied, perceived or communicated."110

The Cablevision II court rejected the Copyright Office's duration analysis because, "[a]ccording to the [DMCA Report], if the work is capable of being copied from that medium for any amount of time, [the duration requirement is met]. The problem with this interpretation is that it reads the 'transitory duration' language out of the statute.",111

105. Id. at $111-12$.

106. Id. at 113 .

107. 17 U.S.C. § 117 (a) (2006).

108. DMCA REPORT, supra note 17 , at 113.

109. Id. at 113-14.

110. Id. at 111 .

111. Cartoon Network LP v. CSC Holdings, Inc. (Cablevision II), 536 F.3d 121, 129 (2d Cir. 


\section{B. Cablevision II's Timeline Analysis}

The Cablevision II court acknowledged that data held in RAM can sometimes be sufficiently permanent as to satisfy the duration requirement. ${ }^{112}$ In so doing, the court discussed MAI Systems Corp. v. Peak Computer, Inc., a case in which a computer repair company loaded copyrighted software into a computer's RAM so employees could view the system error log and diagnose system problems. ${ }^{113}$ In MAI Systems, the Ninth Circuit held that the software loaded into RAM was fixed as required by the Copyright Act. ${ }^{114}$ The court's rationale was that the loading of software into RAM creates a copy under the Copyright Act because "the copy created in the RAM can be 'perceived, reproduced, or otherwise communicated.",115 The Cablevision II court construed MAI Systems as "holding that loading a program into a computer's RAM can result in copying that program. We do not read MAI Systems as holding that... loading a program into... RAM always results in copying. Such a holding would read the 'transitory duration' language out of the definition." 116 In fact, the court found the holding of MAI Systems "unsurprising, because it seem[ed] fair to assume that" the program was embodied in RAM for "at least several minutes." "117

The Cablevision II holding that RAM copies can amount to copies as defined by the Copyright Act is rational because "RAM copies in today's environment often last far longer than momentarily - even for days or months."118 So, by extension, "[a] crucial aspect of [the] MAI ruling [must have been] that the RAM copies at issue there [were] long-lasting. The case cannot support a reading that momentary passage through RAM creates a 'copy' that implicates the proprietor's rights."119

The Cablevision II opinion provides a clear interpretation of the Copyright Act's duration requirement for an embodiment to be fixed, namely, that the duration requirement is to be understood as strictly that-a duration of time or timeline analysis. ${ }^{120}$ Further, the court

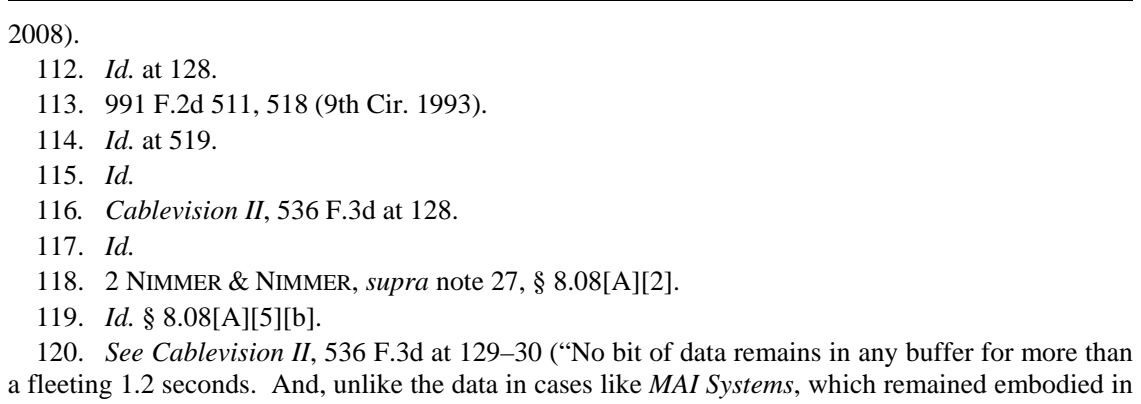


provided limits for both what is greater than a transitory duration (embodiment in RAM for at least several minutes, as in MAI Systems), ${ }^{121}$ and what is not greater than a transitory duration (embodiment in RAM for 1.2 seconds, as in the RS-DVR). ${ }^{122}$ Unfortunately, the court's interpretation provides very little guidance for other courts analyzing similar cases. Whether data embodied in RAM for between 1.2 seconds and several minutes is sufficiently permanent to meet the duration requirement remains unanswered. Moreover, other courts have no guidance on whether other factors that could "alter the duration analysis significantly" ${ }^{\prime 23}$ are present in the case before them since those factors are left unspecified in Cablevision II.

\section{The Purpose-Driven Durational Requirement: An Alternative Test}

1. Problems with the Timeline Analysis

Cablevision II's timeline analysis is fraught with problems. First, the test is impossibly vague. As a practical matter, the only situation to which the timeline analysis can definitely be applied is Cablevision's RS-DVR device as it existed at the time of the decision. Indeed, even future iterations of Cablevision's system could fall short of the timeline analysis. The Cablevision II court stated that "loading a program into a computer's RAM can result in copying that program." 124 So it is possible that some version of the RS-DVR could embody data in RAM with sufficient permanence to satisfy the duration requirement under the timeline analysis. For example, the timeline analysis provides no clear answer on whether the data are sufficiently permanent to exceed a transitory duration if enhancements are made to the RS-DVR (or a software bug emerges) that causes the buffered data to remain in RAM for more than 1.2 seconds. Considering non-Cablevision II RS-DVR scenarios, it is easy to imagine a case in which an embodiment of data always or sometimes lands in the magic range of uncertain fixationnamely, between 1.2 seconds and several minutes.

the computer's RAM memory until the user turned the computer off, each bit of data here is rapidly and automatically overwritten as soon as it is processed.").

121. See id. at 128 (agreeing with the MAI Systems holding that data copied into RAM met the duration requirement because "the program was embodied in RAM for at least several minutes").

122. See id. at 129-30 (holding that the duration requirement is not met when "no bit of data remains in any buffer for more than a fleeting 1.2 seconds").

123. Id. at 130 .

124. Id. at 128 . 
Second, while providing adequate results in certain circumstances, the timeline analysis is an anachronistic approach to the duration requirement when computer-driven processes are at issue. The timeline analysis works best when addressing embodiments of works viewed and understood by human beings in real-time. For example, the Cablevision II court noted approvingly that, under the MAI Systems facts, the timeline analysis works nicely: (1) a computer malfunctions, such that it will no longer boot up; (2) a computer technician loads unlicensed software into RAM; (3) while doing so, the technician is able to make use of the unlicensed software to diagnose and repair the system. ${ }^{125}$ The software was embodied in RAM long enough for humans to initiate it, view its output, and use it to repair systems. ${ }^{126}$ The court reasoned that the timeline analysis was met because "the program was embodied in the RAM for at least several minutes." ${ }^{27}$ The court also mentioned that a different result could have potentially occurred if the computer had been shut down within seconds or less after loading the program. ${ }^{128}$ While not expressly stating why several minutes meets the duration requirement but slightly more than a second does not, a reasonable assumption is that the difference lies in the fact that a human technician would be unable to view or perform anything in seconds or a fraction of a second but could easily do so in several minutes. In other words, the timeline analysis is rooted in the logic of 1908 copyright jurisprudence: “an 'infringing' copy must be perceptible to the naked eye."129

In contrast, the timeline analysis is weakest when computer-based, automated processes embody the data at issue. Because of the rapidity with which computers are able to complete tasks, many embodiments of data that should meet a timeline analysis will inevitably fail it, thus protecting would-be infringers.

Data are often embodied in RAM with insufficient permanence for humans to possibly perceive or understand in real-time. Nonetheless, these embodiments could perform functions against that data identical to, and even more far-reaching than, the software used in MAI Systems. Cablevision II's timeline analysis effectively draws a line with humanbased operations on the infringing side and automated, computer-based

\footnotetext{
125. Id. at $127-28$.

126. MAI Sys. Corp. v. Peak Computer, Inc., 991 F.2d 511, 518 (9th Cir. 1993).

127. Cablevision II, 536 F.3d at 128.

128. Id. at 128-29.

129. 2 NimMER \& NiMmER, supra note 27, § 8.08[A][1]; see also White-Smith Music Publ’g Co. v. Apollo Co., 209 U.S. 1, 17 (1908) ("It is not susceptible of being copied until it has been put in a form which others can see.”).
} 
operations on the noninfringing side. It makes no legal difference to the timeline analysis that both sides are performing precisely the same function-the only thing that matters is the length of time the function takes to perform. Practically, however, the difference is huge. Because the computer-based side inevitably takes a very short time to perform, the timeline analysis will confirm that its embodiment was insufficiently permanent to meet the duration requirement. The reproduction will therefore not constitute an infringing copy. In contrast, the human-based operation will inevitably take longer, and in all likelihood, at least a few minutes longer than a computer-based operation. The timeline analysis will respectively confirm its embodiment as sufficiently permanent to meet the duration requirement and to make the reproduction an infringing copy. Declaring one copy infringing and another lawful, based solely on the relative time it takes to delete the embodiment, produces arbitrary results and illustrates a weakness of the timeline analysis.

Finally, there will almost always be factors that were not present in Cablevision II that could "alter the duration analysis significantly."130 These factors are neither defined nor does the Cablevision II court indicate under what circumstances they might come into play. Other courts could conceivably recognize that certain factors would provide the timeline analysis with more reasonable results. One such factor would be whether the purpose underlying the embodiment of the data was dependent on human perception and understanding or mere computerbased processes. As discussed above, human-based processes inevitably take longer to complete than their computer-based counterparts. If courts looked at this as a factor on which their analysis was based, the timeline analysis's results may be more rational. Unfortunately, the Cablevision II court implicitly rejected this factor when it concluded that Cablevision's RS-DVR failed the duration requirement without addressing the purpose underlying the embodiment of data whatsoever. ${ }^{131}$ In the end, other than knowing that courts should look at transitory duration on a timeline, it is difficult to see how Cablevision II's timeline analysis will produce rational results.

130. Cablevision II, 536 F.3d at 130.

131. Id. 


\section{Alternative Analyses}

\section{a. Defining Fixed — Take One}

A work is fixed when its embodiment in a copy is sufficiently permanent to permit it to be perceived, reproduced, or otherwise communicated for a period of more than transitory duration. ${ }^{132}$ The Copyright Act defines three distinct elements of fixed. An embodiment can be fixed when it is (1) perceived, (2) reproduced, or (3) otherwise communicated. ${ }^{133}$ Courts can construe this definition in several ways. Under one construction, "for a period of more than transitory duration" strictly modifies the final element in the series, i.e., the copy's ability to be "otherwise communicated." This definition would include any time a copy is embodied with sufficient permanence that anyone or anything could ever perceive or reproduce it; then the embodiment would be fixed and a copy could exist. This interpretation would also mean that an embodiment would not be sufficiently permanent to be fixed if it could not be otherwise communicated for a transitory duration or less, which would naturally require a definition of transitory.

Applied to the facts of Cablevision II, this interpretation of fixed would have changed the outcome completely. The buffering of content in RAM by the RS-DVR clearly embodied the data in a copy with sufficient permanence that it could be reproduced. Indeed, buffering the data for reproduction is part of what the RS-DVR does. Data are split off from the typical broadcast stream and sent to several RAM buffers so that the system can reformat the content stream and determine whether a customer record request exists. ${ }^{134}$ The primary ingest buffer, which runs a query to see whether any customer record requests exist, ${ }^{135}$ satisfies the reproduced requirement for an embodiment of data to be fixed under this interpretation. The primary ingest buffer's sole purpose is to buffer the data while the RS-DVR determines whether any customer record request exists so that it can subsequently copy the data onto the Cablevision server. This clearly meets the definitional requirement that the copy be embodied with sufficient permanence so that it can be reproduced-that is the whole point of the primary ingest buffer. On the other hand, the buffering performed by the BMR would fall under the "otherwise

132. 17 U.S.C. § 101 (2006).

133. Id.

134. Cablevision II, 536 F.3d at 124.

135. Id. 
communicated for a period of more than transitory duration" part of section 101 of the Copyright Act under this alternative interpretation. ${ }^{136}$ As with Cablevision II's construal of the Act, determining whether the BMR buffering constituted copyright infringement would require a definition of transitory, though it would be unnecessary to continue the analysis once it was determined that the primary ingest buffer's embodiment of data was fixed.

The first problem with this interpretation of fixed is that the question of what constitutes sufficient permanence to meet the duration requirement-namely, what is transitory duration-remains unanswered. Second, why courts should read the duration requirement out of the statute for data that can be perceived or reproduced but still apply it to data that can be otherwise communicated is unclear.

\section{b. Defining Fixed - Take Two}

Another way to interpret section 101's definition of fixed is to construe "of more than transitory duration" as modifying all three elements of the definition of fixed but understanding transitory duration as a measurement not strictly confined to a timeline. For example, if Black's Law Dictionary's definition of transitory applies, the statute would read: "A work is 'fixed' in a tangible medium of expression when its embodiment in a copy . . . is sufficiently permanent or stable to permit it to be perceived, reproduced, or otherwise communicated for a period" greater than merely "passing from place to place."137 In other words, if the purpose of the perception, reproduction, or communication is merely a conduit for the information to move from place to place, the work is not embodied with sufficient permanence to meet the duration requirement. This is the purpose-based analysis. The court in Cablevision II rejected the notion that a copy was fixed outside of a timeline because it thought that this would "read[] the "transitory duration' language out of the statute."138 Of course, the court is assuming that it should understand transitory duration strictly on a timeline. Once the notion of transitory is separated from a strict timeline and understood in terms of the purpose being served by the RAM embodiment, the duration requirement remains alive and well.

\footnotetext{
136. See 17 U.S.C. $\S 101$.

137. See BLACK's LAW Dictionary 1637 (9th ed. 2009).

138. See Cablevision II, 536 F.3d at 129 (stating that an interpretation which made a work "capable of being copied from that medium for any amount of time" is unacceptable because "it reads the 'transitory duration' language out of the statute”).
} 
Other courts have used a purpose-based analysis when considering the definitional duration requirement of section 101. For example, in 2004, the Fourth Circuit held:

When an electronic infrastructure is designed and managed as a conduit of information and data that connects users over the Internet, the owner and manager of the conduit hardly "copies" the information and data in the sense that it fixes a copy in its system of more than transitory duration. Even if the information and data are "downloaded" onto the owner's RAM or other component as part of the transmission function, that downloading is a temporary, automatic response to the user's request, and the entire system functions solely to transmit the user's data to the Internet. ${ }^{139}$

Certain amici curiae who submitted briefs in favor of the Cablevision II holding were apparently aware that a purpose-based construal of fixed would damage their interests and sought to deter any such reading by focusing on the ubiquity of RAM copies in practically all interactions with technology. ${ }^{140}$ For example, in one such brief, amici stated:

It is a truism of the digital age that digital devices must copy information into transient "buffers" in random access memory (RAM) in order to process that information. None of the digital devices now available in the marketplace-computers, cell phones, personal digital assistants (PDAs), MP3 and compact disk players ... could function without the regular and automatic creation of such transient "buffer" copies ....

... [T]he District Court ignored the plain text and legislative history of the Copyright Act, both of which make clear that such ephemeral, transitory reproductions are not sufficiently "fixed" to constitute “copies.” ... Under the District Court's ruling, [in Cablevision I,] each and every lawful use of a digital device of any kind-turning on a digital TV, or browsing a website on the Internet-becomes an act fraught with potential copyright liability: If the content involved is protected by copyright, the user will need some form of "authorization," or some other defense, for creating the temporary buffer copies that these devices automatically and inevitably make when processing digital information. That rule would create... an

139. CoStar Group, Inc. v. LoopNet, Inc., 373 F.3d 544, 550-51 (4th Cir. 2004).

140. Brief of Amici Curiae Law Professors in Support of Defendants-CounterclaimantsAppellants \& Reversal at 1-3, Cablevision II, 536 F.3d 121 (Nos. 07-1480-cv(L), 07-1511cv(CON)), 2007 WL 6101595. 
exclusive monopoly over the "right to read" (or watch, or hear, or access in any way) digital information. ${ }^{141}$

While it is true that Cablevision's RS-DVR "inevitably and automatically" embodies the data in RAM when determining whether any customer record requests exist, it does so specifically because that is the way that the system was designed. ${ }^{142}$ Further, whether the data buffered in RAM by Cablevision's RS-DVR are as "ephemeral and transitory" as amici contend is questionable. Amici's entire statement is based on the proposition that digital devices buffer data as a necessary byproduct of their basic operation. ${ }^{143}$ In contrast, Cablevision's primary ingest buffer is not merely buffering data in RAM as a natural consequence of being a digital device-or, in this case, of being one small component of a larger, digital-based system. Rather, the primary ingest buffer performs an operation outside of natural digital functioning: it queries the database of customer record requests to determine whether any exist for the content it is currently buffering. ${ }^{144}$

Because the primary ingest buffer performs an operation outside of the scope of the basic RAM processing that occurs for any digital device, the timeline analysis, adopted by the Cablevision II court-and the amici quoted above ${ }^{145}$-falls short. Founding the analysis upon the everchanging technology on which the RS-DVR essentially relies will prove to be a fickle friend of RS-DVR providers. For example, the timeline analysis is an ally of the RS-DVR provider on Monday, before a software bug emerges, because the system in which data were embodied takes a mere 1.2 seconds to perform the customer record request checks. On Tuesday, after a software bug emerges and the timeline analysis becomes an enemy of the same RS-DVR service provider because the buffering process now takes ten minutes to accomplish the customer

141. Id.

142. See Cablevision II, 536 F.3d at 124 ("If a customer has requested a particular program, the data for that program move from the primary buffer into a secondary buffer, and then onto a portion of one of the hard disks.”).

143. See Brief of Amici Curiae Law Professors, supra note 140, at 1 ("It is a truism of the digital age that digital devices must copy information into transient 'buffers' in random access memory (RAM) in order to process that information.”).

144. Cablevision II, 536 F.3d at 124.

145. See Brief of Amici Curiae Law Professors, supra note 140, at 3 (urging the Cablevision II court to reject the district court's conclusion that "all transient RAM reproductions-no matter how brief or fleeting - constitute fixed 'copies' within the meaning of the Copyright Act. Instead, this Court should hold that momentary RAM reproductions that are automatically and necessarily created as digital devices processes digital data, and which are destroyed almost immediately after they are created—such as the buffer copies in Cablevision's RS-DVR system—are not fixed copies.” (emphasis added)). 
record request checks. On Monday, the RS-DVR did not violate the Copyright Act; on Tuesday, it did. Such drastic differences in result show how flawed the timeline analysis is when applied to automated processes performed by computer systems.

If courts continue to follow the timeline analysis, a fair determination of whether the device infringes the content providers' exclusive rights will either produce unfair results or require hopelessly technical evaluations of the hardware platforms as well as the software efficiencies that underlie the processes. If, for example, a cable company releases the RS-DVR II, but, for whatever reason, the data remain embodied in the primary ingest buffer for five minutes instead of 1.2 seconds, the RSDVR II may very well infringe on a copyright. Using the timeline analysis, a court could simply declare the system to directly infringe on the content providers' exclusive copyrights, in which case Cablevision's RS-DVR would be lawful, but the RS-DVR II, which performs the exact same function as the RS-DVR, would be unlawful. On the other hand, the court could attempt to perform an analysis taking into account the relative system power and software efficiencies. For example, if the RSDVR has four times the system power and one-fourth of the system inefficiencies as the RS-DVR II, the court may conclude that the RSDVR II does not infringe. Unfortunately, this type of analysis becomes hopelessly complex, time consuming, and expensive.

Not only is the timeline analysis impossible to apply rationally, it arguably runs contrary to the underlying motivation behind the Supreme Court's pursuit of media-neutral copyright jurisprudence-typified by the holding in Sony. ${ }^{146}$ The basic purpose against which courts should construe the Copyright Act is to "stimulate artistic creativity for the general public good" by "secur[ing] a fair return for an 'author's' creative labor." 147 By tying the legality of RS-DVR services to a strict timeline $^{148}$ the Second Circuit tethered its jurisprudence to the technology of the moment, thereby overlooking this basic purpose of copyright law.

In contrast, if the purpose-based analysis is used, courts will be able to fairly determine whether a RAM-based embodiment of data infringes, not by the duration of time the copy remains embodied, but by whether

\footnotetext{
146. See Sony Corp. of Am. v. Universal City Studios, Inc., 464 U.S. 417, 431-32 (1984) ("'When technological change has rendered its literal terms ambiguous, the Copyright Act must be construed"” such that by incentives, artistic creativity is stimulated "'for the general public good."” (quoting Twentieth Century Music Corp. v. Aiken, 422 U.S. 151, 156 (1975))).

147. Id. at 432.

148. See Cablevision II, 536 F.3d at 130.
} 
the RAM copy is a natural byproduct of digital operation and the purpose behind the embodiment. A RAM copy-such as the RS-DVR's primary ingest buffer, for example-would meet the duration analysis because the purpose of the buffer copy was not merely to pass the data from one location to another. Because the RS-DVR's primary ingest buffer performs an operation against the data that is not intrinsic to the essential operation of digital devices-specifically, to query the data regarding whether any customer record requests exist-it would constitute an infringement of the content holders' copyrights. Furthermore, as other cable television companies develop their own version of the RS-DVRwhich will surely happen ${ }^{149}$ - the inconsistent results of the timeline analysis will not occur. As long as the RAM-based copy at issue has a purpose outside of what is allowed by the statute-namely, use for a purpose greater than moving the data from place to place-it will infringe. This will be true regardless of hardware power, software efficiencies, or even software bugs. The purpose-based analysis, therefore, provides a rational framework upon which courts can determine the permanence of data embodiments. Moreover, by providing courts a media-neutral, rational basis on which to construe the meaning of the Copyright Act, the purpose-based analysis meets the basic purpose of the Copyright Act—as elucidated in Sony. ${ }^{150}$

Applying the purpose-based analysis to the facts of Cablevision II, the content providers might have prevailed. As stated above, because the RS-DVR's primary ingest buffer reproduces the embodiment in a copy for a purpose greater than to move the data from place to place, it would meet the duration requirement of section 101—making the RAM copies an unlawful reproduction of the plaintiffs' protected content. This result certainly would not mean the end of RS-DVR and similar technologies. A cable television company using RS-DVR technology could acquire additional licenses for the content before offering the RS-DVR service to its customers. Alternatively, if a cable television company does not obtain licenses, and if the purpose-based analysis leads to a finding that the RS-DVR service infringes, the company could still defend by invoking Sony. The defense essentially would be that, just like the Betamax in Sony, the RS-DVR service facilitates fair-use copying by

149. Other cable companies will certainly follow Cablevision's lead in developing remote DVR technology because they will increase profit "by reducing their operational costs through removing the need for DVR boxes in subscriber households.” Megan Cavendar, Recent Development, RSDVR Slides Past Its First Obstacle and Gets the Pass for Full Implementation, 10 N.C. J.L. \& TECH. 145, 164 (2008).

150. Sony, 464 U.S. at 432. 
consumers. As the Second Circuit concluded in Cablevision II, "on the facts of this case, copies produced by the RS-DVR system are 'made' by the RS-DVR customer, and Cablevision's contribution to this reproduction does not warrant the imposition of direct liability."151

\section{CONCLUSION}

Cablevision's RS-DVR is a "complex system requiring numerous computers, processes, networks of cables, and facilities staffed by personnel twenty-four hours a day and seven days a week."152 The system takes a giant leap forward in DVR technology by allowing television watchers to time-shift television programs without the need for a set-top DVR. In recording the data, however, the RS-DVR buffers the content through two areas of RAM, both of which occur independently of any customer input. One area of RAM reformats the data to make it more efficient; the other runs a query to determine whether any existing customer record requests exist for the currently buffered content. No area of RAM in the RS-DVR holds more than 1.2 seconds of programming data.

The Second Circuit concluded that 1.2 seconds was insufficiently permanent to constitute a fixed copy as required by the Copyright Act. As such, the court held the RS-DVR's RAM-based copying lawful and validated Cablevision's decision not to seek additional licenses in implementing its RS-DVR service. The court provided a timeline analysis for determining when an embodiment in a copy is sufficiently permanent to be fixed. It concluded that several minutes is a sufficient time to consider an embodiment fixed and 1.2 seconds is insufficient. Furthermore, the court noted that some factors could substantially change the analysis.

The purpose-based analysis provides a superior method for determining when RAM-based copies are sufficiently permanent as to be fixed. Contrary to the timeline analysis, the purpose-based analysis looks at how the data are being used and is able to provide both a clear guideline for courts to apply to diverse factual scenarios as well as avoid the unfairness and hypertechnical evaluations inevitable with the timeline analysis. The purpose-based analysis provides that an embodiment of

151. Cablevision II, 536 F.3d at 133.

152. Id. at 125 (quoting Twentieth Century Fox Film Corp. v. Cablevision Sys. Corp. (Cablevision I), 478 F. Supp. 2d 607, 612 (S.D.N.Y. 2007), rev'd in part, vacated in part, Cablevision II, 536 F.3d 121). 
data in a copy is fixed when it is sufficiently permanent such that it can be perceived, reproduced, or otherwise communicated for a period or use greater than moving the data from place to place. Applying the purposebased analysis to Cablevision II, the primary ingest buffer would likely have met the duration requirement, and the data would have been sufficiently fixed as to constitute a copy under the Copyright Act. Finally, the timeline analysis is intrinsically tied to the underlying technology at issue and thereby runs counter to the Supreme Court's admonition to embrace the basic purpose of the Copyright Act. In contrast, the purpose-based analysis, by providing a rational, medianeutral means to evaluate copyright infringement claims, gives courts a way to determine the permanence of data embodiments while following the spirit of Sony. 